УДК: 339.732.2+339.92

JEL Classification: F330, F340, 0570

DOI 10.35433/ISSN2410-3748-2020-2(27)-1

Dr Olga Vikarchuk

Żytomierski Uniwersytet Państwowy

im. Iwana Franki, Ukraina

http://ORCID 0000-001-7574-5347

Dr Hanna Lewandowska,

Państwowa Uczelnia im. S. Batorego,

Skierniewice, Polska

\author{
Mgr Viktoriia Vikarchuk \\ Analityk Ryzyka Operacyjnego \\ Erste Group Bank AG
}

\title{
POLITYKA INWESTYCYJNA EUROPEJSKIEGO BANKU INWESTYCYJNEGO NA PRZYKLADZIE UKRAINY I POLSKI
}

Europejski Bank Inwestycyjny (European Investment Bank- EBI) jest jedna z głównych instytucji Unii Europejskiej (UE) oraz jednym z największych kredytodawców udzielających pomocy kredytowej nie tylko krajom członkowskim, ale również krajom spoza UE. Ma on na celu ułatwienie i przyspieszenie procesu transformacji zróżnicowanych gospodarek państw członkowskich w jeden system, co wpływa bezpośrednio na interesy obywateli. Wartości i cele

Unii Europejskiej determinuja kierunki polityki inwestycyjnej EBI ${ }^{1}$. Polityka ta skupia się przede wszystkim na innowacyjności; podnoszeniu kwalifikacji ludności; wsparciu sektora małych i średnich przedsiębiorstw (MŚP); przeciwdziałaniu zmianom klimatu; budowaniu infrastruktury strategicznej na terenie Unii Europejskiej.

Przyjęta przez EBI polityka inwestycyjna jest zgodna z ustalonymi celami polityki UE. Natomiast w państwach spoza UE bank nie przywiduje szczegółowych planów i strategii. Trudno jest więc ocenić zgodność tej polityki w krajach nie będacych członkami UE. $W$

\footnotetext{
${ }^{1}$ www.europa.eu/european-union/about-eu/eu-in-brief_en, [dostęp 13.03.2018]. Do głównych celów i wartości UE należą: pokój, wsparcie wartości UE i dobrobytu obywateli UE, wolność, bezpieczeństwo i sprawiedliwość w przestrzeni bez granic wewnętrznych, zrównoważony rozwój opartego na trwałym wzroście gospodarczym i stabilności cen, na wysoce konkurencyjnej gospodarce rynkowej umożliwiającej pełne zatrudnienie i postęp społeczny oraz na ochronie środowiska, zwalczanie wykluczenia społecznego i dyskryminacji, postęp naukowo-techniczny, spójność gospodarcza, społeczna i terytorialna oraz solidarność między członkami, ochrona bogatej różnorodności kulturowej, unii gospodarczej i walutowej stanowią główne cele Unii Europejskiej.
} 
przypadku Ukrainy jest to dodatkowo brak postęu we wdrażaniu reform, korupcja nierozwiazany konflikt ukraińsko - rosyjski. Czynniki te to największe zagrożenia dla wzrostu gospodarczego Ukrainy i szerszej wspótpracy z UE, w tym z EBI.

Stowa kluczowe: Europejski Bank Inwestycyjny, Polska, Ukraina, polityka inwestycyjna, system finansowy.

\section{THE INVESTMENT POLICY OF EUROPEAN INVESTMENT BANK BASED ON THE EXAMPLES OF UKRAINE AND POLAND}

European Investment Bank (EIB) is one of the main EU institutions as well as one of the largest multilateral borrowers and lenders. It is an institution that provides credit assistance not only to EU Member States, but also to countries outside European Union. The aim is to facilitate and accelerate the process of transforming the diverse economies of the Member States into a single system, which also directly affects the interests of citizens. The values and objectives of the European Union determine the directions of the EIB's investment policy. The policy is primarily focused on innovation; improving the qualifications of the population; supporting for the small and medium-sized enterprise (SME) sector; addressing climate change; building strategic infrastructure within the European Union.

Based on the analysis of consistency of EIB's investment policy in Ukraine and Poland, it can be concluded that the EIB's activities in Poland are in line with established investment policy objectives and support EU strategies and objectives. However, a detailed plan and an investment strategy is not foreseen in countries outside the EU, making it difficult to assess the consistency of investment policy in Ukraine. Furthermore, the instability of the political situation, the lack of progress in the implementation of reforms and the Ukrainian-Russian

conflict in the east are the greatest threats to Ukraine's economic growth and wider cooperation with the EU, including the EIB.

Key words: European Investment Bank, investment policy, financial system, investment project.

Wprowadzenie. Międzynarodowy system finansowy ewoluuje wraz ze wzrostem liczby procesów transformacji. Zmiany te mają wpływ na powstawanie międzynarodowych instytucji finansowych tworzących zróżnicowane sieci powiązań finansowych i gospodarczo - handlowych między podmiotami tego systemu. Najwięcej instytucji finansowych o zasięgu międzynarodowym powstało po II wojnie światowej. Celem głównym ich działalności było m.in. wsparcie rozbudowy krajów zniszczonych przez działania wojenne oraz poprawa i rozbudowa stosunków walutowo finansowych.

Jedną z głównych instytucji finansowych UE jest Europejski Bank Inwestycyjny (EBI). Celem jego powołania było ułatwienie i przyspieszenie procesu transformacji gospodarek państw członkowskich. EBI jako 
międzynarodowa instytucja finansowa (multilateral development bank), udziela pomocy kredytowej krajom członkowskim, krajom stowarzyszonym z UE i krajom spoza UE.

Celem opracowania jest porównanie polityki inwestycyjnej banku na przykładzie Polski, innych państw UE i krajów poza unijnych ze szczególnym uwzględnieniem Ukrainy.

Metodologia. Metodami wykorzystanymi w pracy była kwerenda literatury przedmiotu, opracowania EBI oraz ogólnie stosowane metody statystyczne. Do analizy wykorzystano również metody jakościowe oraz metody porównawcze. Zakres czasowy badań obejmuje lata 1999-2019 w przypadku Polski i innych krajów UE oraz lata 2007 - 2019 w przypadku Ukrainy.

Geneza, zarządzanie i struktura EBI. Wynik działań wojennych i ich skutków miał wpływ na powstanie idei i zbudowanie ponadnarodowej współpracy w różnych obszarach gospodarczych. Integracja krajów Unii Europejskich doprowadziła do powstania wspólnego obszaru gospodarczego, w którym zachodzą powiązania gospodarcze, polityczne oraz finansowe między państwami członkowskimi. Istotnym elementem tych powiązań stała się współpraca na rzecz spójności gospodarczej, społecznej i terytorialnej. Wymagało to jednak utworzenia infrastruktury instytucjonalno - finansowej.

Jednym z banków wspierających proces transformacji jest Europejski Bank Odbudowy i Rozwoju (European Bank for Reconstruction and Development $)^{2}$, powołany w 1990 roku. Jego celem jest wspieranie sektora prywatnego w krajach Azji Centralnej, na wybrzeżu Morza Śródziemnego i Europie Środkowo - Wschodniej. Bank wspiera obszary związane m.in. z infrastrukturą transportową, technologiami teleinformatycznymi, rolnictwem, rozwojem małych i średnich przedsiębiorstw, zrównoważonym zużyciem energii oraz bezpieczeństwem nuklearnym w państwach postsowieckich.

\footnotetext{
${ }^{2}$ www.gov.pl/web/finanse
} 
W 1994 roku utworzono Europejski Fundusz Inwestycyjny³, którego celem jest finansowanie inwestycji sektora Małych i Średnich Przedsiębiorstw. Wykorzystywany jest $\mathrm{w}$ tym przypadku kapitał wysokiego ryzyka i inne instrumenty finansowania oparte o podział ryzyka. Produktami oferowanymi przez EFI jest kapitał wysokiego ryzyka i mikrofinansowanie nowych i innowacyjnych podmiotów gospodarczych, gwarancje kredytowe związane z kredytami oraz pomoc państwom UE i państwom stowarzyszonym w rozwijaniu rynków kapitału wysokiego ryzyka. Większościowym udziałowcem EFI jest EBI (1958).

Współcześnie EBI jest organem i bankiem UE. Struktura jego działalności to połączenie zarządzania publicznego i ładu korporacyjnego zgodnie z którym ustalane są cele banku i sposoby ich osiągnięcia.

EBI funkcjonuje w oparciu o statut ${ }^{4}$, który został sporządzony jako załącznik do Traktatu o funkcjonowaniu Unii Europejskiej ${ }^{5}$. Statut ten określa prawa i obowiązki EBI. W sytuacjach przekraczających zasięg traktatu, zarząd EBI może kierować się Zasadami Nadzoru Korporacyjnego OECD ${ }^{6}$, a także zasadami określonymi przez Bazylejski Komitet Nadzoru Bankowego ${ }^{7}$ i Europejski Urząd Nadzoru Bankowego (2011) ${ }^{8}$.

Struktura organizacyjna EBI składa się z różnych departamentów, które mają za zadanie przygotowywać i wdrażać decyzje kierownictwa. Zajmują się one zarządzaniem środkami finansowymi, ewaluacją projektów wraz z ich finansowaniem, przeprowadzaniem niezbędnych analiz obejmujących warunki ekonomiczne i finansowe oraz oceną ryzyka związanego z działaniami EBI.

\footnotetext{
${ }^{3}$ https://europa.eu/european

${ }^{4}$ Część V, Tytuł I, Rozdział 5 Traktatu o Unii Europejskiej, Dz.U.C143 z 11.06.2005 i Dz.U.C642 z 8.03.2008

${ }^{5}$ Traktat z Maastricht o Unii Europejskiej podpisany w lutym 1992 roku zmienił nazwę Europejskiej Wspólnoty Gospodarczej na Wspólnotę Europejską, Dz.U. 2004.90.864/30

6 www.oecd.org/daf/ca/corporategovernanceprinciples; por. także: D. Dobija, I. Koładkiewicz (red), Ład Korporacyjny, Wolters Kluwer, Warszawa 2010

7 Bazylejski Komitet ds. Nadzoru Bankowego. Podstawowe zasady efektywnego nadzoru bankowego, wyd. Bank Rozliczeń Międzynarodowych, 2012, por. także: www.bis.org; www.knf.gov.pl

${ }^{8}$ www.eba.europa.eu
} 
Grupę EBI tworzy Europejski Bank Inwestycyjny, czyli bank transgraniczny oraz Europejski Fundusz Inwestycyjny. Celem pierwszego z nich jest udostępnianie kapitału na inwestycje leżące w interesach UE, natomiast drugiego zwiększanie dostępu podmiotów gospodarczych należących do sektora Małych i Średnich Przedsiębiorstw do innowacyjnych źródeł finansowania. Udziałowcami tej grupy są EBI (58,5\%) i Unia Europejska, reprezentowana przez Komisję Europejską (29,7\%), prywatne i publiczne instytucje finansowe Państw Członkowskich i Turcji $(11,8 \%)^{9}$.

Polityka inwestycyjna EBI. Dla instytucji finansowych niezbędne jest określenie polityki pozwalającej na podejmowanie skutecznych decyzji inwestycyjnych. Polityka ta jest nieodzownym elementem skutecznego zarządzania powierzonymi zasobami oraz kapitałem własnym. Stanowi ona rezultat wcześniej przyjętych założeń i kierunków działalności organizacji. W przypadku inwestycji publicznych, jak i prywatnych jest to plan, określający zasady i maksymalny poziom zaangażowania finansowego. Polityka inwestycyjna EBI powiązana jest ściśle z wartościami i celami UE ${ }^{10}$.

EBI działa we wszystkich sektorach gospodarki, zapewniając długoterminowe wsparcie finansowe dla zrównoważonych inwestycji, przyczyniających się do realizacji celów polityki unijnej w Europie i poza nią ${ }^{11}$. Polityka inwestycyjna EBI w głównej mierze ukształtowana jest poprzez cele nadrzędne, do których należą: spójność społeczna i gospodarcza oraz cele polityki publicznej takie jak: innowacje, wsparcie sektora MSP, rozwój infrastruktury i ochrona środowiska. Cele te są fundamentem działalności EBI

\footnotetext{
${ }^{9}$ www.eif.europa.eu/news_centre/publications/register_shareholders.pdf, [dostęp 30.11.2017].

${ }^{10}$ www.europa.eu/european-union/about-eu/eu-in-brief_en, [dostęp 13.03.2018]. Do głównych celów i wartości UE należą: pokój, wsparcie wartości UE i dobrobytu obywateli UE, wolność, bezpieczeństwo i sprawiedliwość w przestrzeni bez granic wewnętrznych, zrównoważony rozwój opartego na trwałym wzroście gospodarczym i stabilności cen, na wysoce konkurencyjnej gospodarce rynkowej umożliwiającej pełne zatrudnienie i postęp społeczny oraz na ochronie środowiska, zwalczanie wykluczenia społecznego i dyskryminacji, postęp naukowo-techniczny, spójność gospodarcza, społeczna i terytorialna oraz solidarność między członkami, ochrona bogatej różnorodności kulturowej, unii gospodarczej i walutowej stanowią główne cele Unii Europejskiej.

${ }^{11}$ Europejski Bank Inwestycyjny, www.eib.org/attachments/general/the_eib_at_a_glance_pl.pdf, [dostęp 27.01.2017].
} 
oraz jego planów operacyjnych istotnych dla organizacji niekomercyjnych. Metody działania i wykonywanie zadań wynikają z przyjętej strategii ${ }^{12}$.

Europejski Bank Inwestycyjny funkcjonuje na zasadach non - profit. Środki finansowe umożliwiające prowadzenie działalności pochodzą m.in. z:

- wkładów państw członkowskich obliczanych na podstawie wartości Produktu Narodowego Brutto (PNB) danego kraju i liczby jego mieszkańców,

- pożyczek zaciąganych na międzynarodowym rynku kapitałowym oraz

- emisja obligacji do wysokości 250\% kapitału zakładowego.

W latach 80. XX wieku udział pożyczek udzielonych przez EBI krajom spoza Unii Europejskiej stanowił ok. $10 \%$, w latach 90 . było to ok. $15 \%$, a w latach 2015 - 2019 ok. $9 \%{ }^{13}$.

EBI posiada szczegółowo określone priorytety dotyczące działalności kredytowej w krajach UE. Poza UE celem Banku jest wspieranie rozwoju i współpracy.

\section{Poziom, kierunki i struktura finansowania EBI w Polsce.} Zrealizowane przez EBI transakcje kredytowe w poszczególnych państwach uzależnione są od przyjętej przez Bank polityki inwestycyjnej, klimatu ekonomicznego w danym kraju lub/i jego członkostwo w UE.

W Unii Europejskiej istnieją dwa rodzaje członkostwa:

- zwyczajne;

- stowarzyszone.

Każde państwo może zostać członkiem zwyczajnym po uzyskaniu aprobaty organów Wspólnoty oraz ratyfikacji tej aprobaty przez państwa członkowskie. Natomiast członkostwo stowarzyszone łączy w sobie dwie kategorie: stowarzyszone obszary niesamodzielne i stowarzyszenia państw. Jest również jednym z pierwszych etapów prowadzących do integracji ze Wspólnotą.

\footnotetext{
12 J. Zawadzki, Zarządzanie Organizacjami Non-profit, Wyd. Forum Naukowe, Poznań 2007, s. 55.

${ }^{13} \mathrm{https}$ ://eur-lex.europa.eu/legal-content
} 
Polska już od 1990 roku jako państwo stowarzyszone, a więc 14 lat przed akcesją z UE (2004r.) otrzymywała pomoc finansową z EBI. W latach 19902003 pomoc dotyczyła 57 kredytów (bez linii kredytowych) wspierających przebudowę gospodarki i administracji oraz system prawny pozwalający na implementację prawodawstwa Unii Europejskiej. Najwięcej środków finansowych przeznaczone zostało na transport i komunikację (ok. 42\%), telekomunikację (ok. 14\%), infrastrukturę i budownictwo (ok. 12\%) oraz rozwój obszarów wiejskich (ok. 7\%). Ogółem w latach 1990-2003 Polska otrzymała z EBI ok. 7,3 mld Euro. Wartościowo największa kwota (ok. 3 116,7 milionów euro) została przeznaczone na rozwój transportu i komunikacji oraz telekomunikacji (ok. 1035 mln euro). Na rozwój infrastruktury i budownictwa oraz obszarów wiejskich przeznaczono odpowiednio ok. 900 milionów euro i ok. 483 miliony euro.

Lata 2004-2019 charakteryzowały się znacznym zwiększeniem wolumenu pomocy kredytowej EBI dla Polski. Liczba udzielonych kredytów w tych latach wzrosła do 509 (bez linii kredytowych). Najwięcej środków finansowych przeznaczono analogicznie, jak w latach poprzednich, na rozwój transportu i komunikacji (ok. 27 409,1 mln euro). Nowym obszarem na rozwój którego przeznaczono środki finansowe EBI były usługi (7 638,5 miliona euro) oraz gospodarka odpadami (ok. 5,8 miliona euro). Wzrosły również, w porównaniu z latami 1990 - 2003, środki finansowe na restrukturyzację sektora przemysłowego i energetycznego (odpowiednio ok. 3, 69 mln euro i ok. 4, $1 \mathrm{mln}$ euro).

Tabela 1.

Struktura sektorowa kredytów udzielonych Polsce przez EBI w latach 1990-2019

\begin{tabular}{|l|c|c|}
\hline \multicolumn{1}{|c|}{ Sektor } & Liczba kredytów & Udział (\%) \\
\hline Ochrona zdrowia & 12 & 2,12 \\
\hline Rolnictwo, leśnictwo i & 4 & 0,73 \\
\hline
\end{tabular}




\begin{tabular}{|l|c|c|}
\hline rybołówstwo & & 2,65 \\
\hline Edukacja & 15 & 12,71 \\
\hline Przemysł & 39 & 6,90 \\
\hline Energetyka & 93 & 16,37 \\
\hline Rozwój obszarów wiejskich & 14 & 2,47 \\
\hline Infrastruktura i budownictwo & 29 & 5,13 \\
\hline Sieć wodno - kanalizacyjna & 18 & 3,17 \\
\hline telekomunikacja & 219 & 38,58 \\
\hline Transport i komunikacja & 1 & 0,18 \\
\hline Gospodarka odpadami & 51 & 8,99 \\
\hline usługi & 568 & $100(\%)$ \\
\hline Razem & & \\
\hline
\end{tabular}

Źródto: opracowanie własne na podstawie: www.eib.org/projects/loan/list/index.htm, [dostęp 12.09.2020].

Akcesja Polski z UE miała znaczący wpływ na dynamikę liczby i wartości udzielanych przez EBI kredytów. Związane było to i w dalszym ciągu jest $\mathrm{z}$ polityką gospodarczą - transformacją strukturalną (konwergencja) ${ }^{14}$ realizowaną przez UE dotyczącą wyrównywania szans między regionami (zgodnie z $\left.\mathrm{NUTS}^{15}\right)$.

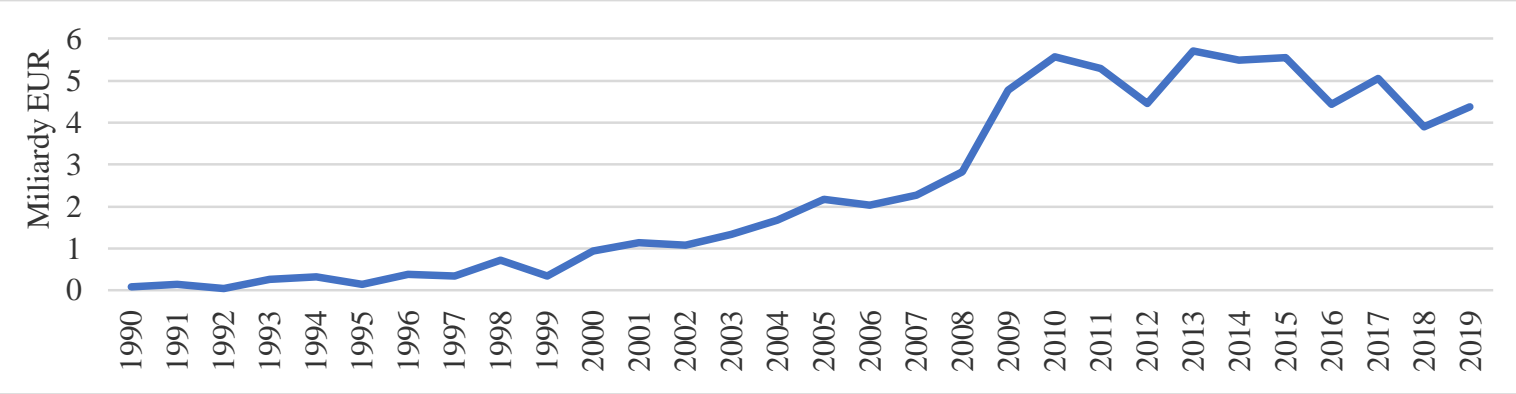

Źródło: opracowanie własne na podstawie: www.eib.org/projects/loan/list/index.htm, [dostęp 12.09.2020].

Wykres 1. Wartość kredytów udzielonych Polsce przez EBIT w latach 1990-2019 (mld euro).

\footnotetext{
${ }^{14}$ A. Kutan, T. Yigit, Nominal and Real Stochastic Convergence of Transition Economies, Journal of Comparative Economics, $\mathrm{nr}$ 34, 2004

${ }^{15}$ Rozporządzenie (WE) nr 1059/2003 Parlamentu Europejskiego i Rady z 26.05.2003r. w sprawie ustalenia wspólnej klasyfikacji Jednostek Terytorialnych do Celów Statystycznych (NUTS), Dz.Urz. UE L $154 \mathrm{z}$ 21.06.2003r.
}

(C) Vikarchuk Olga, Lewandowska Hanna, Vikarchuk Viktoriia 
W 1990 roku Polska za pośrednictwem EBI otrzymała ok. 1,45 mld euro, a w 2000 roku było to 9,41 mld euro. W 2013 roku wartość kredytów udzielonych Polsce wynosiła ok. 57 mld euro, jednak od 2014 roku można zauważyć nieznaczny spadek wartości udzielonych kredytów. W 2015 roku było to ok. 55 mld euro, w 2016 roku ok. 44 mld euro, a w latach 2017-2019 było to odpowiednio ok. 51 mld euro, ok. 39 mld euro i ok. 44 mld euro. Zauważalny spadek wartości udzielonych kredytów w latach 2018-2019 wynoszący odpowiednio 24\% i 14\% w stosunku do 2017 roku to wynik częściowo zakończonego procesu konwergencji i przyjętej polityki gospodarczej.

Analizując średnioroczną wartość i liczbę kredytów EBI udzielonych Polsce można zauważyć, że nie występuje korelacja pomiędzy wartością kredytów i ich ilością. Najwyższy poziom kredytowania miał miejsce w latach 2007-2009, przy czym lata te charakteryzują się najniższą liczbą transakcji kredytowych - por. wykres 2.

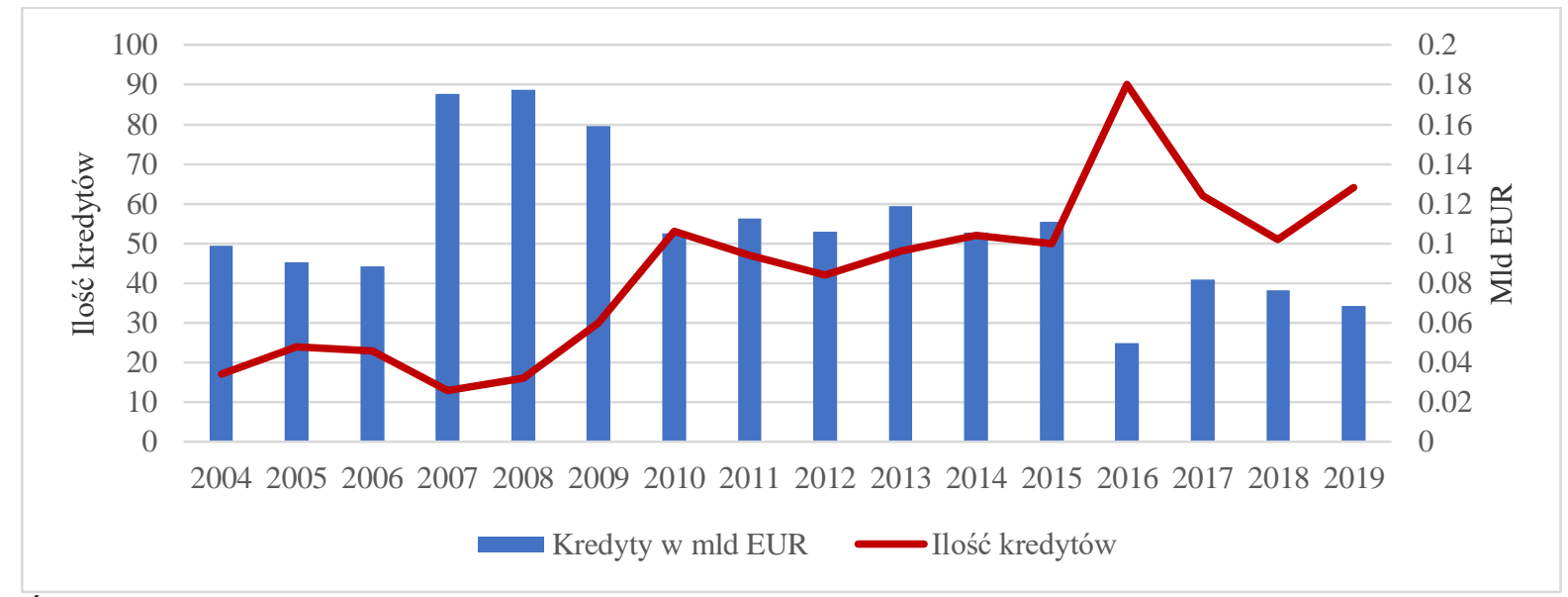

Źródło: opracowanie własne na podstawie: www.eib.org/projects/loan/list/index.htm, [dostęp 13.09.2020].

Wykres 2. Średnioroczna wartość oraz liczba kredytów EBI w Polscew latach 2004-2019

Projekty finansowane przez EBI w latach lat 2007-2009 to projekty związane przede wszystkim z przemysłem, transportem i komunikacją, rozwojem obszarów miejskich i modernizacją infrastruktury. Sektory te są istotne i niezbędne dla zapewnienia trwałego wzrostu gospodarczego, 
zwiększania konkurencyjności gospodarki kraju oraz podnoszenia poziomu życia mieszkańców. W 2016 roku udzielono największą liczbę kredytów, lecz o najmniejszym poziomie kapitału.

W latach 2004-2019 roku Polska znalazła się w grupie 5 państw, którym udzielono największego wsparcia finansowego (ok. 65 mld euro), z tym że ok. $19 \%$ tej kwoty stanowiły linie kredytowe. Największym beneficjentem EBI okazała się Hiszpania (ok. 144,7 mld euro), Włochy (ok. 134,5 mld euro, Niemcy i Francja. Było to odpowiednio ok. 107,8 mld euro i 95,6 mld euro por. wykres 3.

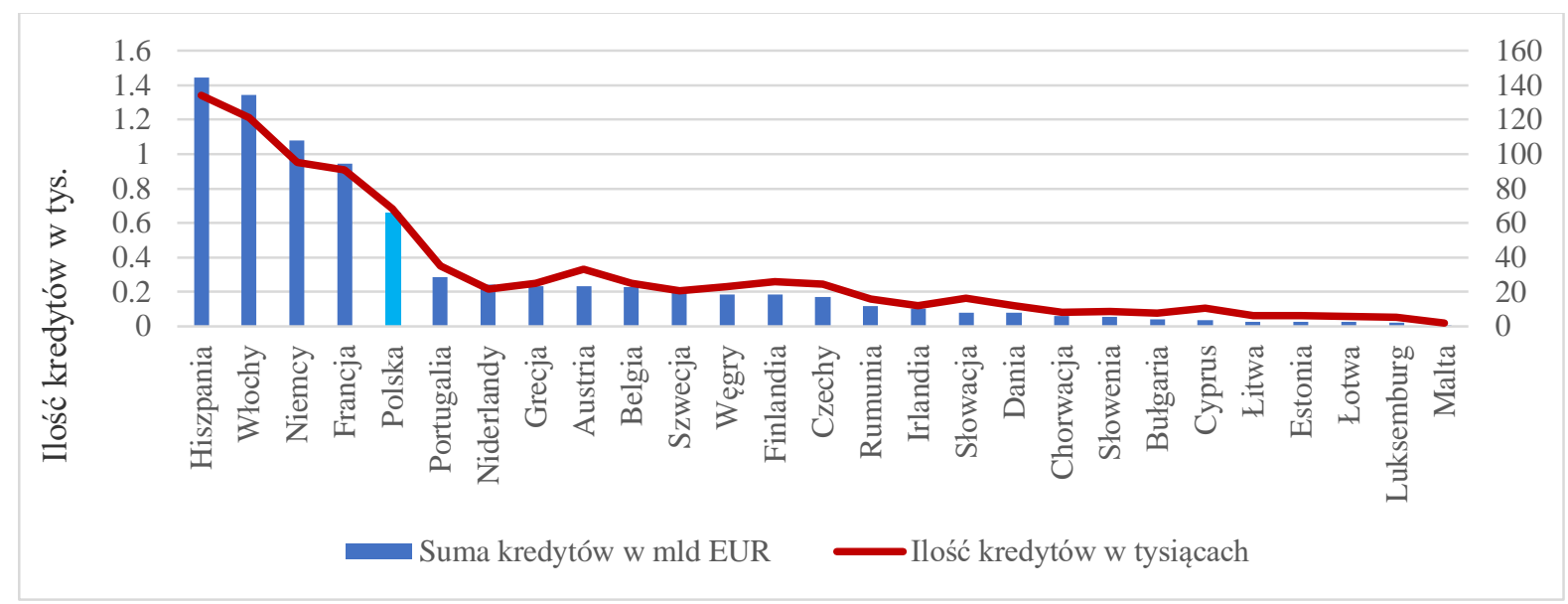

Źródto: opracowanie wtasne na podstawie: www.eib.org/projects/loan/list/index.htm, [dostęp 13.09.2020].

Wykres 3. Wartość oraz liczba udzielonych przez EBI kredytów krajom UE w latach 2004-2019 roku (mld euro)

Średnia wartość kredytu udzielonego przez EBI Polsce w latach 20042019 wynosząca ok. 96 mln euro była o ok. 29\% wyższa od średniej wartości kredytów, jakie udzielono innym krajom UE. Wśród krajów członkowskich powyżej tej średniej znalazły się również Węgry. Wynikało to głównie z wysokiej atrakcyjności inwestycyjnej tych krajów związanej z ich położeniem geopolitycznym, stabilnej polityki gospodarczej i polityki konwergencji przyjętej przez Unię Europejską - por. wykres 4. 


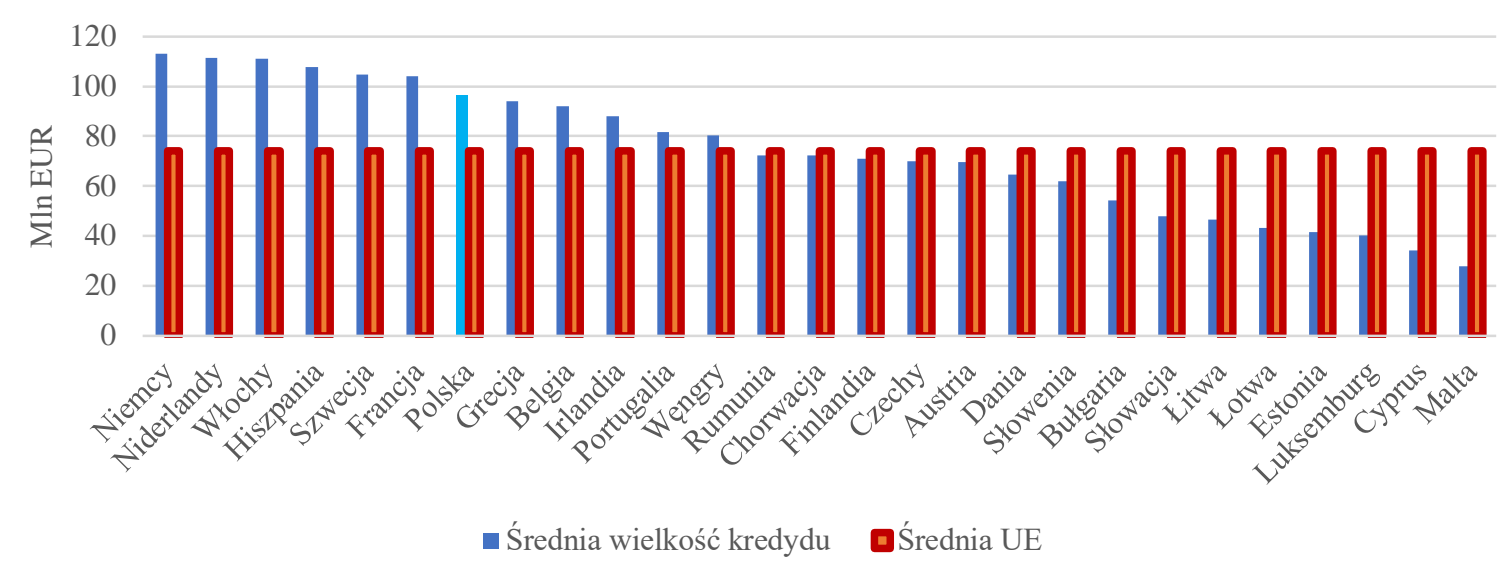

Źródto: opracowanie wtasne na podstawie: www.eib.org/projects/loan/list/index.htm, [dostęp 13.09.2020].

Wykres 4. Średnia wartość kredytów zaciągniętych przez państwa UE w EBI w latach 2004-2019

Najwięcej kredytów zostało udzielono na projekty zapewniające trwały wzrost gospodarczy, zwiększanie konkurencyjności i rozwój obszarów wiejskich. Uwagę należy również zwrócić na środki, jakie zostały przekazane przez EBI na rozwój sektora telekomunikacji. W 2007 roku była to wartość ok. 824,5 mln euro, z czego ok. 50\% zostało dedykowane na rozwój mobilnych usług transmisji danych ${ }^{16}$.

Poziom, kierunki i struktura finansowania EBI na Ukrainie. Procesy polityczne zachodzące w Europie środkowo - wschodniej miały wpływ na rozpad Związku Radzieckiego. W wyniki tych przemian w 1991 roku niezależnym państwem stała się Ukraina. Pierwsze lata samodzielnego bytu charakteryzowały się spadkiem produkcji, wysoką inflacją i korupcją. Czynniki te w znacznym stopniu hamowały proces przemian. Pomimo tych trudności od 1994 roku na Ukrainie rozpoczął się proces budowy gospodarki wolnorynkowej. Podjęte reformy strukturalne kreowane przez kolejne ekipy rządzące spowalniały jednak lub przyśpieszały całość procesów prowadzących do rozwoju gospodarczego. Pomimo wielu niekorzystnych zdarzeń np. wojna rosyjsko - ukraińska, wojna w Donbasie itp. Ukraina w 2017 roku podpisała

\footnotetext{
${ }^{16}$ www.eib.org (dostęp 25.04.2020)
} 
układ stowarzyszeniowy z UE. Porozumienie to pozwala Ukrainie na przyśpieszenie procesu reform, których efektem końcowym ma być kcesja z Unią Europejską.

Przejście Ukrainy od gospodarki centralnie sterowanej do gospodarki rynkowej wymagało i nadal wymaga znacznych nakładów finansowych. Dużą rolę zaczął więc odgrywać Europejski Bak Inwestycyjny (EBI), którego jednym z celów jest udzielanie kredytów na finansowanie projektów o zasięgu międzynarodowym i regionalnym nie tylko państwom - członkom UE, ale również krajom nie będącymi członkami UE - por. wykres 5.

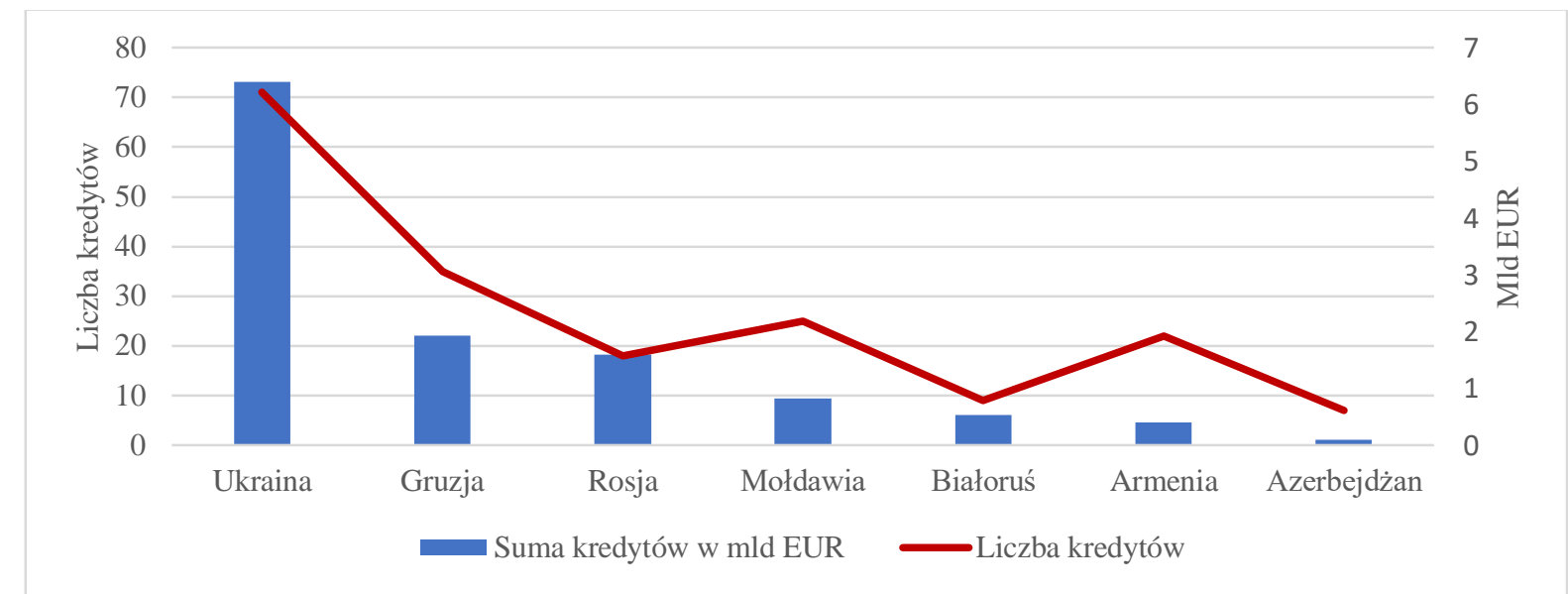

Źródlo: opracowanie własne na podstawie: www.eib.org/projects/loan/list/index.htm, [dostęp 13.09.2020].

Wykres 5. Suma oraz liczba udzielonych przez EBI kredytów w Europie Wschodniej, na Kaukazie Południowym oraz w Rosji w latach 2003-2019

W 2003 roku Rosja była pierwszym krajem spoza UE, który otrzymał kredyt z EBI. Ogółem w latach 2003-2019 skorzystała z 18 kredytów na łączną kwotę ok. 1, 6 mld euro. Spośród innych krajów byłego Związku Radzieckiego największą pomoc EBI można zauważyć na Ukrainie (od 2007 roku). Sfinansowano wówczas 71 projektów na ogólną kwotę ok. 6,4 mld euro. Ze znacznej pomocy skorzystała również Gruzja, realizując w oparciu o środki finansowe EBI, 35 projektów na ogólną kwotę ok. 1,93 mld euro (od 2010 roku). Inne republiki korzystające w latach 2003-2019 z pomocy finansowej Europejskiego Banku Inwestycyjnego to Mołdawia (ok. 0,8 mld euro), Białoruś 
(ok. 0,5 mld euro), Armenia (ok. 0,4 mld euro) i Azerbejdżan (ok. 0,09 mld euro).

Analizując średni poziom kredytowania jednego projektu można zauważyć, że najwyższy średni poziom występował na Ukrainie, w Rosji, na Białorusi i Gruzji. Było to odpowiednio: ok. 90 mld euro, ok. 88 mld euro, ok. 59 mld euro i ok. 55 mld euro. Średnie wielkości tych kredytów są około dwukrotnie wyższe niż w przypadku pozostałych krajów tego regionu.

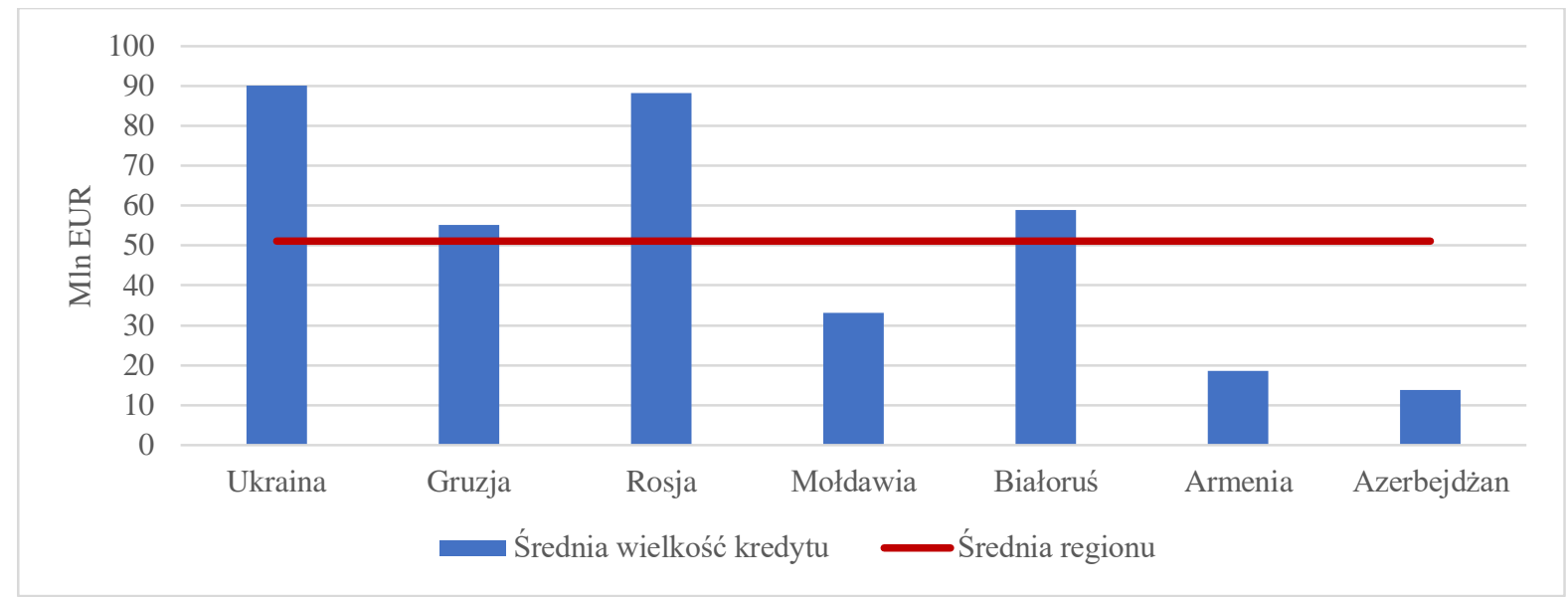

Źródto: opracowanie wlasne na podstawie: www.eib.org/projects/loan/list/index.htm, [dostęp 21.04.2018].

Wykres 6. Średni poziom kredytowania EBI w Europie Wschodniej, na Kaukazie Południowym oraz Rosji w latach 2007-2019.

Pierwsza operacja kredytowa na Ukrainie, z udziałem środków EBI, miała miejsce w 2007 roku. Był to projekt związany z modernizacją autostrady M-06 Kijów - Brody. Najniższy poziom kapitału otrzymanego z EBI to lata 20082010. W latach 2011-2012 suma udzielonych kredytów wynosiła ok. 0,64 mld euro. W 2013 roku nastąpił spadek do poziomu ok. 0,41 mld euro, natomiast od 2014 roku można zauważyć znaczący wzrost sumy udzielanych kredytów. W 2015 roku było to 1,26 mld euro - por. wykres 7 . 


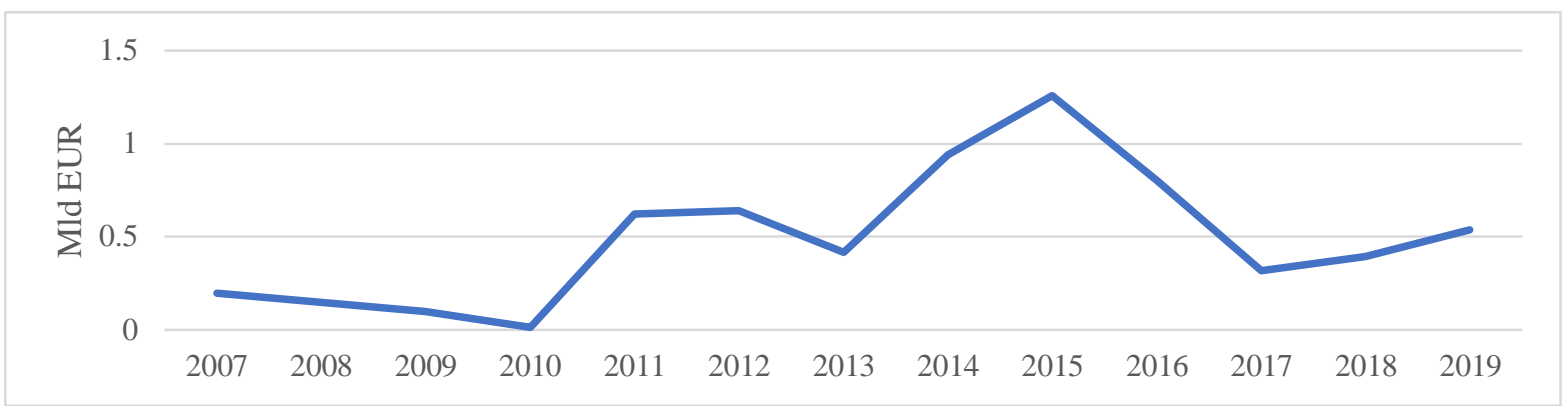

Źródto: opracowanie własne na podstawie: www.eib.org/projects/loan/list/index.htm, [dostęp 13.09.2020].

Wykres 7. Suma udzielonych przez EBI kredytów na Ukrainie w latach 2007-

Suma udzielonych przez EBI kredytów oraz liczba finansowanych projektów miała wpływ na średnioroczną ich wartość w latach 2007-2019 - por. wykres 7.

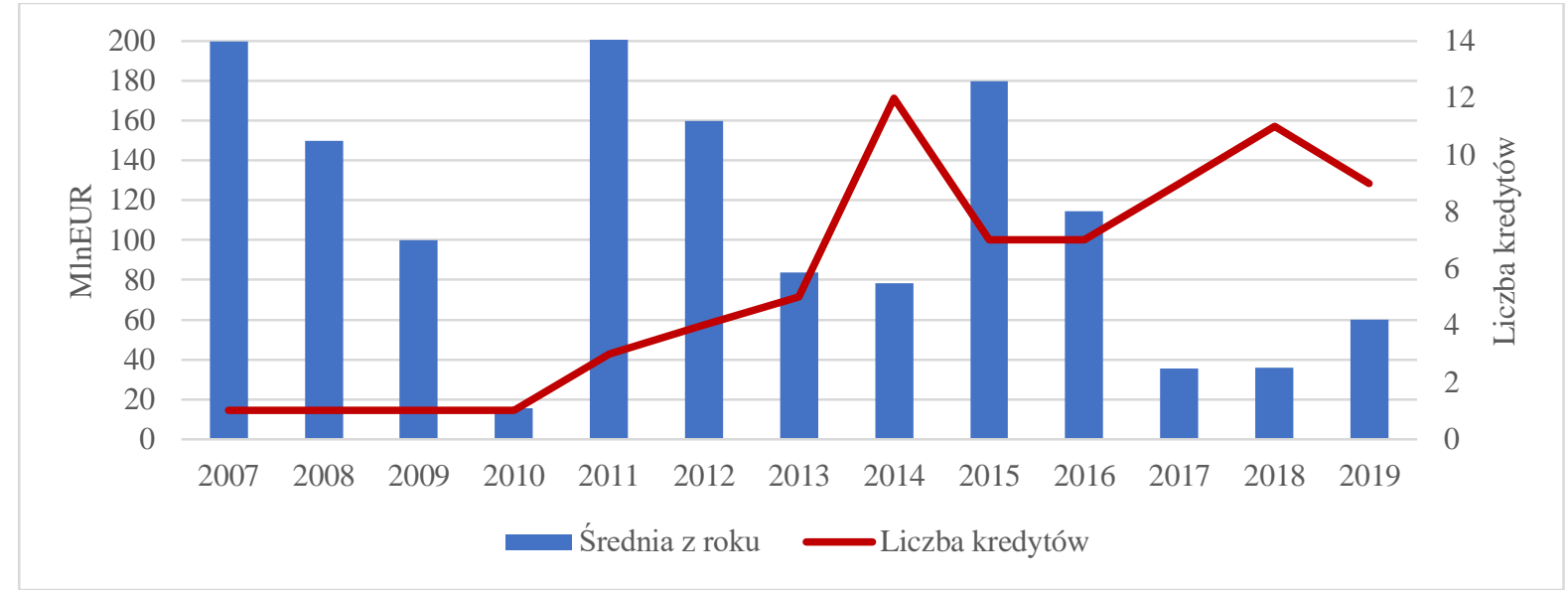

Źródto: opracowanie wtasne na podstawie: www.eib.org/projects/loan/list/index.htm, [dostęp 13.09.2020].

Wykres 7. Średnioroczny poziom oraz liczba kredytów EBI na Ukrainie w latach 2007-2019

Analizując średnioroczną wartość kredytu w zestawieniu z liczbą tych kredytów można zauważyć, że nie wykazują one korelacji. Oznacza to, że średnioroczny poziom kredytowania w wysokości ok. 0,2 mld euro odnosił się tylko do jednego kredytu (2007 rok). W latach 2008-2009 ok. 0,15 mld euro i ok. 0,1 mld euro to również średnioroczna wartość tylko jednego kredytu. 
Największa liczba kredytów w przeliczeniu na ich średnioroczną wartość to 2014 i 2018 rok. Było to odpowiednio 12 i 11 kredytów.

W latach 2007-2013 dominującymi sektorami na Ukrainie ze względu na finansowanie EBI były sektory związane z infrastrukturą i energetyką oraz linie kredytowe. Wsparcie EBI uzyskały także projekty wdrażane w sektorze przemysłu oraz związane z rozwojem obszarów miejskich. W 2016 roku częścią programu wsparcia Ukrainy było, ogłoszone w marcu 2014 roku, finansowanie sektora edukacyjnego. Celem wszystkich przyjętych projektów i programów jest wzrost konkurencyjności gospodarki, poprawa bezpieczeństwa energetycznego i polepszenie jakości życia obywateli Ukrainy.

Działalność kredytowa EBI na Ukrainie jest mniej rozwinięta pod względem sektorów, na które środki są udostępnione. Trudno także zauważyć stały trend w wysokości i liczbie kredytów EBI dla Ukrainy. Przyczyną tego jest brak szczegółowych planów i strategii przyjętych przez Bank w państwach spoza UE. Bank może kierować się założeniami polityki inwestycyjnej przy podjęciu decyzji o finansowaniu projektów, które w większym stopniu zależą od innowacyjności i wspólnych korzyści poszczególnych przedsięwzięć.

Podsumowanie. Europejski Bank Inwestycyjny jest jednym z organów Unii Europejskiej. Jego działalność koncentruje się na udzielaniu długoterminowych kredytów, finansujących projekty wpływające na rozwój infrastruktury, ochronę środowiska, zwiększenie potencjału wytwórczego i wzrost konkurencyjności gospodarki UE. W okresie swojej działalności EBI udzielił kredytów w łącznej wysokości 1450 biliona Euro.

W latach 2004-2019 skumulowana suma oraz liczba udzielonych kredytów Polsce była ok. 3 - razy większa niż w państwach grupy luksemburskiej i helsińskiej. Również średni poziom udzielonego kredytu był o ok. 30\% wyższy od średniej unijnej. Znaczący poziom zainteresowania EBI Polską wynika głównie z jej położenia geopolitycznego i stabilnej polityki ekonomicznej. Kredyty EBI finansowały w Polsce rozwój transportu i 
komunikacji oraz obszarów wiejskich. Związane były również $\mathrm{z}$ restrukturyzacją przemysłu i budową sieci wodociągowo - kanalizacyjnej, rozwojem sektora usługowego i modernizacją telekomunikacji. Działania EBI zgodnie z przyjęta strategią przyczyniły się w Polsce do przyśpieszenia procesu konwergencji i wzrostu poziomu jakości życia obywateli.

W państwach spoza UE decyzje finansowe EBI oparte są o ogólne cele polityki inwestycyjnej. Zależą więc $\mathrm{w}$ większym stopniu od innowacyjności i potencjalnych korzyści poszczególnych przedsięwzięć/projektów. Potwierdzeniem tego jest Ukraina, gdzie występuje brak stałego trendu w wysokości i liczbie kredytów pomimo podpisania umowy stowarzyszeniowej z UE. Można również zauważyć niewielką liczbę sektorów, na które EBI udostępnia swoje środki finansowe. Istotny wpływ na decyzje EBI w stosunku do Ukrainy ma również sytuacja polityczna tego kraju, brak istotnego postępu we wdrażaniu przyjętych reform oraz konflikt rosyjsko - ukraiński mający wpływ na ryzyko inwestowania. Na Ukrainie wdrożenie reform strukturalnych w oparciu o model przyjęty przez kraje post komunistyczne staje się więc warunkiem sine qua-non pozwalającym na szersza współpracę z Europejskim Bankiem Inwestycyjnym i Unią Europejską.

\section{REFERENCES}

1. Basel Committee on Banking Supervision (2012). Core principles for effective banking supervision. Retrieved from https://www.bis.org/publ/bcbs230.pdf.

2. Dobija, D. \& Koładkiewicz, I. (2010). Lad Korporacyjny [Corporate Governance]. Warsaw, Poland: Wolters Kluwer [in Polish].

3. Kutan, A. \& Yigit, T. (2004). Nominal and Real Stochastic Convergence of Transition Economies. Journal of Comparative Economics, $n r 34$ [in Polish]. 4. Zawadzki, J. (2007). Zarzadzanie Organizacjami Non-profit [Managing Non-profit Organisations]. Poznan, Poland: Forum Naukowe [in Polish]. 
5. OECD, (2015). G20/OECD Principles of Corporate Governance. Paris, France: $\quad$ OECD $\quad$ Publishing. Retrieved from http://dx.doi.org/10.1787/9789264236882-en.

6. Rozporządzenie (WE) nr 1059/2003 Parlamentu Europejskiego i Rady z 26.05.2003r. w sprawie ustalenia wspólnej klasyfikacji Jednostek Terytorialnych do Celów Statystycznych (NUTS) [Regulation No 1059/2003 of the European Parliament and of the Council from 26.05.2003 on the establishment of a common classification of territorial units for statistics]. Dz.Urz. UE L 154 from 21.06.2003. N.p.

7. Site of Bank for International Settlements. www.bis.org. Retrieved from https://www.bis.org [in English].

8. Site of European Banking Authority. www.eba.europa.eu Retrieved from https://eba.europa.eu [in English].

9. Site of European Investment Bank. www.eib.org. Retrieved from https://www.eib.org/en/index.htm [in English].

10. Site of European Investment Fund. www.eif.europa.eu. Retrieved from http://www.eif.europa.eu/index.htm [in English].

11. Site of European Union. www.europa.eu/european-union. Retrieved from https://europa.eu/european-union [in English].

12. Strona Komisji Nadzoru Finansowego [Site of Financial Supervision Authority]. www.knf.gov.pl. Retrieved from https://www.knf.gov.pl [in Polish]. 13. Strona Ministerstwa Finansów [Site of Ministry of Finance]. www.gov.pl/web/finanse. Retrieved from https://www.gov.pl/web/finanse [in Polish].

14. Traktat o Unii Europejskiej [Treaty of the European Union]. Dz.U.C143 from 11.06.2005 and Dz.U.C642 from 08.03.2008.

Стаття надійшла до редакиії 20.10.2020 